\title{
Populism, localism and the geography of democracy
}

As Clarke cogently explains, anti-politics can be interpreted as growing public disdain for mainstream parties and their politicians. There is a growing 'void' (Mair, 2013) between the citizens and the political class, and this is often articulated in a geographical lexicon: the elite are understood to be concentrated in Westminster, Whitehall and the posh parts of London and the South East. However, this doesn't mean that people are not interested in politics and different forms of populism have been growing in response to the void. Populism is a form of politics that involves claims to speak for the people in a register that is more authentic to the experiences and needs of those people (Boyte and Reissman, 1987; Laclau, 2005). In the present period, this form of politics can take right or left wing forms, and the 'them' against which the people are positioned can include corporate elites, bankers and EU technocrats as well as immigrants and outsiders. While in England populism has been growing on the right (as manifest in support for the United Kingdom Independence Party (UKIP) in other parts of Europe - most notably Greece and Spain - populism has mobilised around a leftist agenda.

In the wake of the growth of anti-politics alongside the electoral threat of UKIP in England, mainstream politicians have looked increasingly exposed, shorn of an emotional connection to the people and bereft of the policy solutions that are adequate to the challenges faced. In this context, all three of the mainstream political parties - Conservative, Labour and Liberal Democrat - have adopted localism as their key political agenda for post-election reform. Mirroring at least some of the criticism levelled against them, England's leading politicians are starting to sound more contrite: they recognise that political power is too centralised; that they don't have all the answers to the pressing concerns of the day; and that the citizenry who could make a contribution are alienated from the political process. Given the need to restrain public spending and the commitment to austerity, most of the citizenry remain cynical about this agenda. David Cameron's articulation of the need for the Big Society was quickly reduced to an argument about the need for volunteers and charities to fill the gaps left by a state in retreat. And yet, support for localism has grown not diminished during the past five years.

The opening words of the Conservative and Liberal Democrat agreement for coalition in government focused on the need for the devolution of power and as David Cameron and Nick Clegg (HM Government, 2010, 7) put it: "We share the conviction that the days of big Government are over; that centralization and top-down control have proved a failure. We believe that the time has come 
to disperse power more widely in Britain today; to recognize that we will only make progress if we help people to come together to make life better. In short, it is our ambition to distribute power and opportunity to people rather than hoarding authority within Government". In the early days of their government this agenda was supported by some modest new rights for local government and communities (to set up schools, engage in neighbourhood planning and elect police commissioners), and with the provision of funding for community organising. However, following the Scottish Independence Referendum and the growing clamour for English devolution (Kenny, 2014), the Government has been much bolder. In its latest announcements for new 'City Deals', the Government are devolving authority and funding for areas like transport, infrastructure, skills and health to some local authorities. This is presented as a way to boost economic innovation and growth by moving political decision-making closer to the ground, unleashing greater democratic engagement and scrutiny of the decisions being made (Heseltine, 2012; RSA, 2014).

While the strongest advocates of this agenda have been on the right of the political spectrum (Blond, 2010; Clark and Mather, 2003; Jenkins, 2004; Norman, 2010), this agenda has been echoed on the left and support for localism features strongly in the Labour Party's policy review (Cruddas and Rutherford, 2014), the interventions made by labour think-tanks (Cox and Muir, 2012; Smith Institute, 2014; Wilson, 2012), and the arguments made by shadow ministers. The left are beginning to rethink their post-war commitment to geographical uniformity and their anathema to the 'postcode lottery' in favour of a commitment to localising political power and decision-making. Localism thus implies a new regime of government, shifting power away from Westminster and Whitehall towards a range of actors including city-regional leaders, Local Economic Partnerships, local authorities, state-funded organisations and citizens. As was the case with the devolution of power to Wales, Scotland and Northern Ireland, new opportunities will be opened up to a new range of actors who have interests in engaging in political life (Raco, 2003). The new localist regime involves a civic offer being made to a range of actors and in turn, its outcome will depend upon the response of those on the ground. As such, there are some major uncertainties about the emerging political geography of localism: (1) Will power really be 'given away'? (2) Will local state-funded bodies and citizens be able and willing to take up the mantle of greater political freedom and capacity? (3) Will these actors be able to make the culture change and relationships necessary to work in new ways? (4) Will the citizenry be able and willing to engage on their own terms with localism? (5) Why, how and for what would people chose to engage?

As yet, we are not able to answer these questions with any certainty but there is a growing body of literature looking at similar democratic experimentation across the globe (Briggs, 2008; Leighninger, 
2006; Smith, 2009). There is a real opportunity for political geographers to engage in the research we now need to unpack this emerging agenda of government. Localism can be understood as a response to the anti-politics described by Clarke; it is a vehicle that potentially gives previously overly controlled local organisations and disengaged citizens the chance to act. If it takes off, localism will expose and remake the political geography of England but it could also reconfigure the political geography of geographers, moving us away from a fascination with the margins to attend to the machinations of the mainstream. As Clarke suggests, and as Clive Barnet and his co-authors have argued for some time (Barnet and Low, 2004; Barnet and Bridge, 2013), our discipline still needs to develop the tools to better understand the geography of democracy. Mapping out the political geography of the present conjuncture to understand the populism of the people alongside efforts to reach and engage the people via localism is a great place to start.

\section{References}

Blond, P. (2010). Red Tory: How left and right have broken Britain and how we can fix it. London: Faber.

Boyte, H. C. and Reissman, F. (1987) (eds) The new populism: The politics of empowerment. Temple University Press.

Briggs, X. de Sousa (2008) Democracy as problem solving: Civic capacity across the globe. Cambridge MA: MIT Press.

HM Government (2010) The Coalition: Our programme for Government. London: Cabinet Office and HM Government.

Clark, G. and Mather, J. (2003) (eds) Total politics: Labour's command state. London: Conservative Policy Unit.

G. Cooke and R. Muir (eds). The relational state Institute for Public Policy Research.

Cruddas, J. and Rutherford, J. (2014) One nation: Labour's political renewal. One Nation Register.

Heseltine, M. (2012) No stone unturned in pursuit of growth. London: HM Government.

Jenkins, S. (2004) Big Bang localism: A rescue plan for British democracy. London: Policy Exchange and Localis.

Kenny, M. (2014) The politics of English nationhood. Oxford: Oxford University Press.

Laclau, E. (2005) On populist reason. London: Verso. 
Leighninger, M. (2006) The next form of democracy: How expert rule is giving way to shared governance ... and why politics will never be the same. Nashville: Vanderbilt University Press.

Norman, J. (2010). The big society: The anatomy of the new politics. Buckingham: The University of Buckingham Press.

Raco, M. (2003) Governmentality, subject-building, and the discourses and practices of devolution in the UK. Transactions of the Institute of British Geographers 28, 1, 75-95.

Royal Society of Arts' City Growth Commission (2014) Unleashing Metro Growth. Royal Society of Arts.

Smith, G. (2009) Democratic innovations: Designing institutions for citizen participation. Cambridge: CUP. 